\title{
ANALISIS DAN DESAIN SISTEM INFORMASI SIMPAN PINJAM PADA KOPERASI SEJAHTERA BERSAMA BANDUNG
}

\author{
Pratiwi $^{1}$, Asti Herliana ${ }^{2}$ \\ ${ }^{1}$ Fakultas Teknik, Universitas Kebangsaan \\ pratiwi.wiie@gmail.com \\ ${ }^{2}$ AMIK, BSI Bandung \\ Jalan Sekolah Internasional No.1-6 Antapani Bandung 40282 \\ asti.ala@bsi.ac.id
}

\begin{abstract}
Sejahtera Bersama Credit Unions is one of the co-operative in Bandung, which is engaged in the savings and loan. Organization should be a place for the growth of community's economic still has some drawbacks so that performance is not optimal. Kind of Information systems in here is still not effective because it is used combination with a manual process for the loan process, it takes a long time for any transactions, but along with the rapid development of technology, then it should be the cooperative problem given a touch of technology as a solution for example as built system information to enable any existing operational. Design method loan information system created using ancillary equipment such as methodology of waterfall, HIPO diagram and three kind of UML diagrams which is usecase diagram, activity diagram and class digram, and then design of database relationships using Microsoft Access 2007 and programming language using Microsoft Visual Basic 6.0. Loan information system is expected to improve the performance of the cooperative itself, because the system is designed with the aim to shorten the time of the transaction so that the cooperative operations can run more effectively
\end{abstract}

Keywords : information systems, Credit Unions, Technology

Abstrak - Koperasi Sejahtera Bersama Bandung merupakan salah satu koperasi di Kota Bandung yang bergerak di bidang simpan pinjam. Organisasi yang seharusnya menjadi wadah untuk pertumbuhan ekonomi masyarakat ini masih memiliki beberapa kekurangan sehingga kinerjanya belum optimal. Sistem informasi yang berjalan disini masih belum efektif karena masih di kombinasikan dengan proses manual untuk proses pinjamannya, hal tersebut memakan waktu lama untuk setiap transakasinya, namun seiring dengan pesatnya perkembangan teknologi, maka sudah seharusnya masalah perkoperasian tersebut diberi sentuhan teknologi sebagai solusi contohnya seperti dibangun sistem informasi untuk memudahkan setiap operasional yang ada. Metode perancangan sistem informasi simpan pinjam yang dibuat menggunakan metodologi waterfall, diagram HIPO, serta tiga diagram UML yang terdiri dari usecase diagram, activity diagram, dan class digram, kemudian perancangan relasi database menggunakan Microsoft Access 2007 dan bahasa pemrograman Microsoft Visual Basic 6.0. Sistem informasi simpan pinjam ini diharapkan dapat meningkatkan kinerja koperasi itu sendiri, karena sistem ini dirancang dengan tujuan mempersingkat waktu transaksi agar operasional koperasi bisa berjalan lebih efektif.

Kata kunci : Sistem informasi, Koperasi Simpan Pinjam, Teknologi. 


\section{PENDAHULUAN}

Koperasi merupakan badan usaha yang berdiri sebagai penggerak ekonomi rakyat yang berdasarkan asas kekeluargaan. Menurut Undang Undang nomor 25 tahun 1992 tentang pokok-pokok perkoperasian bahwa koperasi sebagai organisasi ekonomi rakyat yang bertujuan untuk memajukan kesejahteraan anggota pada khususnya dan masyarakat pada umunya, serta ikut membangun tatanan perekonomian nasional dalam rangka mewujudkan masyarakat yang maju, adil, dan makmur berlandaskan Pacasila dan UndangUndang Dasar 1945.

Koperasi Sejahtera Bersama Bandung adalah koperasi yang bergerak dalam berbagai bidang usaha antara lain yaitu usaha simpan pinjam dan usaha perdagangan yang didirikan pada bulan Januari tahun 2004. Koperasi ini ingin berperan secara aktif dalam upaya membangun dan mengembangkan potensi dan kemampuan ekonomi masyarakat untuk meningkatkan kesejahteraan ekonomi dan sosialnya.

Permasalahan yang dihadapi oleh Koperasi Sejahtera Bersama Bandung dalam menangani kegiatan simpanpinjam sehari-hari adalah dari segi manajemen waktu, dimana dibutuhkan waktu yang cukup lama untuk memvalidasi pengajuan proses pinjaman terhadap anggota. Permasalahan ini muncul dikarenakan tidak adanya suatu sistem yang dapat mencari dan memverifikasi data dalam waktu yang singkat. Permasalahan ini menyebabkan tidak adanya komunikasi yang baik antara manajemen simpanan dan pinjaman yang berimbas pada lambannya setiap proses transaksi yang terjadi.

Penelitian yang membahas tentang sistem informasi simpan pinjam pada koperasi sebelumnya telah dibahas oleh beberapa peneliti. Seperti halnya yang dilakukan oleh Mawaddah dkk pada tahun 2011 dimana pada penelitian tersebut, Mawaddah dkk meneliti pada objek Koperasi Baitul Maal Wat Tamwil (BMT) Ar-Rum. Pada penelitian ini Mawaddah dkk menggunakan metode
Waterfall sebagai metode untuk memecahkan permasalahan sistem dengan hasilnya adalah sebuah rancang bangun aplikasi dengan menggunakan bahasa PHP versi 5.4 dan MySQL sebagai basis datanya[8].

\section{METODE PENELITIAN}

Metode penelitian yang digunakan pada penelitian kali ini adalah dengan menggunakan metodologi waterfall yang dibatasi dan hanya dilakukan hingga tahap implementasi atau coding. Untuk memperoleh data yang diperlukan metode pengumpulan data yang digunakan adalah sebagai berikut :

1. Studi Lapangan (Field Research)

Mencari dan memperoleh data secara langsung dari objek yang diteliti dengan maksud untuk memperoleh gambaran yang cukup jelas mengenai masalah yang dibahas, dengan menggunakan cara sebagai berikut :

a. Pengamatan secara langsung (Observation)

Pengamatan secara langsung atas masalah yang diteliti dan terkait dengan pembahasan, serta mengumpulkan data tertulis yang dibutuhkan.

b. Wawancara (Interview)

Melakukan tanya jawab dengan pejabat yang berwenang atau bagian terkait dengan meminta dan mempelajari dokumen perusahaan yang berhubungan langsung atau relevan dengan objek yang diteliti.

c. Studi Dokumentasi (Historical)

Melakukan studi yang bersumber dari arsip dokumen yang dimiliki perusahaan yang menunjang penelitian ini. Dokumentasi dilakukan terutama untuk mencari data mengenai deskripsi dari perusahaan secara lengkap dan datadata yang berhubungan dengan sistem penyimpanan file atau dokumen.

\section{Studi Kepustakaan}

Kegiatan mencari literatur yang berisi teori yang berkaitan dengan masalah yang akan dibahas, juga berperan sebagai 
sumber data sekunder atau secondary data, termasuk data public yang bersunber dari internet / website. Berdasarkan studi kepustakaan pada penelitian kali ini dibahas 2 objek utama penelitian yakni sistem informasi dan koperasi.

\section{Sistem Informasi}

Sistem menurut beberapa ahli dapat didefinisikan sebagai berikut:

1. Menurut Stalling suatu sistem adalah suatu jaringan kerja dari prosedurprosedur yang saling berhubungan, berkumpul bersama-sama untuk melakukan suatu kegiatan atau untuk menyelesaikan suatu sasaran yang tertentu [1].

2. Dalam pengertian lain suatu sistem dapat diambil pengertian yang pada dasarnya adalah sekelompok unsur yang erat hubungannya satu dengan yang lain, yang berfungsi bersamasama untuk mencapai tujuan tertentu [6].

Informasi dapat diartikan sebagai hasil dari pengolahan data dalam suatu bentuk yang lebih berguna dan lebih berarti bagi penerimanya yang menggambarkan suatu kejadiankejadian yang nyata yang digunakan untuk pengambilan keputusan. Berdasarkan dari pemahaman pengertian sistem dan informasi, maka dapat diambil kesimpulan bahwa sistem informasi merupakan suatu sistem didalam suatu organisasi yang mempertemukan kebutuhan pengelolaan transaksi harian, mendukung operasi, bersifat manajerial dan kegiatan strategi dari suatu organisasi dan menyediakan pihak luar tertentu dengan laporan-laporan yang diperlukan.

Sistem informasi dapat juga didefinisikan sebagai suatu kesatuan sistem di dalam suatu lembaga yang merupakan kombinasi daari orang-orang, fasilitas, teknologi, media, prosedurprosedur dan pengendalian yang ditujukan untuk mendapat jalur komunikasi penting, memproses tipe transaksi rutin tertentu, memberi sinyal kepada manajemen dan yang lainnya terhadap kejadian-kejadian internal dan eksternal yang penting dan menyediakan suatu dasar informasi untuk pengambilan keputusan.

\section{Koperasi}

Pengertian Koperasi berdasarkan UUD Nomor 25 tahun 1992 tentang PERKOPERASIAN bahwa koperasi adalah badan usaha yang beranggotakan orang-orang atau badan hukum koperasi dengan melandaskan kegiatannya berdasarkan prinsip koperasi sekaligus sebagai gerakan ekonomi rakyat yang berdasar atas asas kekeluargaan.

Pendapat lain menurut Arfinal Chaniago mengemukakan tentang perkoperasian bahwa koperasi sebagai suatu perkumpulan yang beranggotakan orang-orang atau badan hukum, yang memberikan kebebasan kepada anggota untuk masuk dan keluar, dengan bekerja sama secara kekeluargaan menjalankan usaha untuk mempertinggi kesejahteraan jasmaniah para anggotanya [1].

\section{PEMBAHASAN}

Koperasi Sejahtera Bersama Bandung adalah koperasi yang bergerak dalam berbagai bidang usaha antara lain yaitu usaha simpan pinjam dan usaha perdagangan yang didirikan pada bulan Januari tahun 2004. Koperasi ini ingin berperan secara aktif dalam upaya membangun dan mengembangkan potensi dan kemampuan ekonomi masyarakat untuk meningkatkan kesejahteraan ekonomi dan sosialnya. Setiap unit usaha dari Koperasi Sejahtera Bersama Bandung dikelola oleh para expertise yang telah memiliki pengalaman di bidangnya, sehingga unit usaha ini bukan hanya mampu tumbuh dan berkembang dan menghasilkan keuntungan, tetapi juga mampu meningkatkan kesejahteraan ekonomi dan sosial masyarakat.

\section{Sistem Berjalan}

Sistem berjalan yang ada pada Koperasi Sejahtera Bersama Bandung adalah sebuah sistem yang masih mengkombinasikan antara sistem yang sudah terkomputerisasi dan sistem yang 
masih manual untuk operasional kantornya sehari-harinya.

Untuk kegiatan simpan pinjam, Koperasi Sejahtera Bersama Bandung dapat dijabarkan dengan proses pendaftaran anggota, proses transaksi simpanan, proses pengambilan simpanan, proses transaksi pinjaman, proses pembayaran angsuran dan proses pembuatan laporan.

a. Proses Pendaftaran Anggota

Setiap calon anggota dari Koperasi

Sejahtera Bersama ini diharuskan mengisi formulir pendaftaran dan menyerahkan kepada petugas kelengkapan identitas diri seperti KTP/SIM, KK, surat keterangan sehat dari dokter dan membayar biaya pendaftaran sesuai dengan ketentuan dari koperasi tersebut. Setelah terdaftar, petugas akan memberikan kartu tanda anggota dan kartu simpanan serta kwitansi pembayaran pendaftaran.

\section{b. Proses Transaksi Simpanan}

Setiap anggota harus membayar simpanan pokok yang dibayarkan 1 kali selama menjadi anggota sebagai modal koperasi dengan nominal yang ditentukan pihak koperasi, lalu simpanan yang rutin dibayarkan setiap bulan yaitu simpanan wajib dengan nominal yang telah ditentukan oleh pihak koperasi, dan simpanan sukarela dengan jumlah nominal bebas diserahkan kepada anggota koperasi. Setiap transaksi selesai, petugas akan memberikan bukti simpanan kepada anggota dan membuat rekapan harian transaksi tersebut.

\section{c. Proses Pengambilan Simpanan}

Setiap anggota yang akan melakukan pengambilan simpanan harus memenuhi syarat diantaranya sudah menjadi anggota minimal selama 6 bulan, simpanan yang dapat dicairkan hanya simpanan sukarela saja. Simpanan pokok dapat diambil ketika anggota memutuskan untuk nonaktif dengan syarat tertentu. Setiap anggota yang memenuhi syarat harus mengisi formulir pengambilan simpanan dan kartu simpanannya lalu memberikannya pada petugas untuk selanjutnya dibuatkan dokumen pengajuan pencairan untuk diberikan kepada Branch Manager (BM) untuk proses persetujuan, simpanan akan segera dicairkan setelah BM menandatangani formulir pengambilan simpanan. Setiap transaksi pengambilan simpanan selesai, petugas akan memberikan bukti pengambilan simpanan dan membuat rekapan harian transaksi tersebut.

\section{d. Proses Transaksi Pinjaman}

Pada proses transaksi pinjaman terdapat persyaratan yang harus dipenuhi oleh anggota antara lain sudah menjadi anggota minimal 6 bulan, dengan jumlah pinjaman maksimal $80 \%$ dari jumlah simpanan pokok ditambah simpanan sukarela anggota tersebut, setiap anggota diharuskan mengisi formulir pengajuan pinjaman dan melengkapi kelengkapan lain-lain seperti slip gaji dan rekening listrik kepada petugas, setelah itu petugas akan meminta konfirmasi dari menejemen simpanan untuk mengetahui jumlah total dari simpanan anggota tersebut, selanjutnya dokumen pengajuan pinjaman yang sudah lengkap akan diberikan kepada Branch Manager (BM) untuk proses penyetujuan / acc. Biasanya proses ini akan membutuhkan waktu yang cukup lama dengan jangkauan $1-4$ minggu. Setelah hasil pengajuan tersebut dikeluarkan oleh BM, petugas akan memberikan konfirmasi kepada anggota yang melakukan pengajuan tersebut dan melakukan proses pencairan dana bila pengajuan pinjaman tersebut di setujui oleh BM.

\section{e. Proses Pembayaran Angsuran}

Angsuran pinjaman yang harus dilakukan oleh anggota bernilai tetap setiap bulan nya berdasarkan nominal yang ditentukan koperasi selama 1 tahun, dan akan dikenakan denda untuk setiap keterlambatan yang terjadi. Setelah proses pembayaran angsuran selesai petugas akan memberikan bukti pembayaran angsuran dan membuat rekapan harian transaksi tersebut. 
f. Proses Pembuatan Laporan

Proses pembuatan laporan yang dilakukan oleh petugas berupa laporan data anggota, laporan transaksi simpanan, laporan pengambilan simpanan, laporan transaksi pinjaman, dan laporan pembayaran angsuran yang diberikan kepada Branch Manager (BM) setiap harinya.

Secara detail, proses berjalan dari Koperasi Sejahtera Bersama Bandung, dijabarkan dalam usecase diagram dan activity diagram berikut ini.

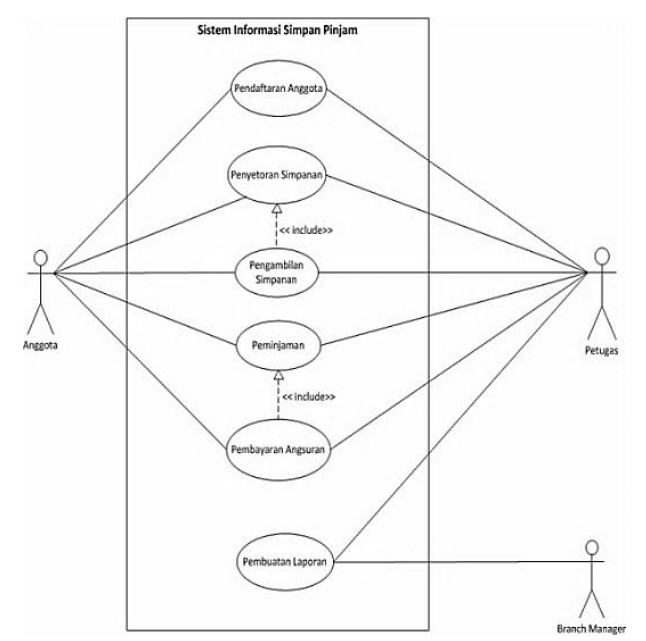

Gambar 1.

Usecase Diagram Sistem Berjalan

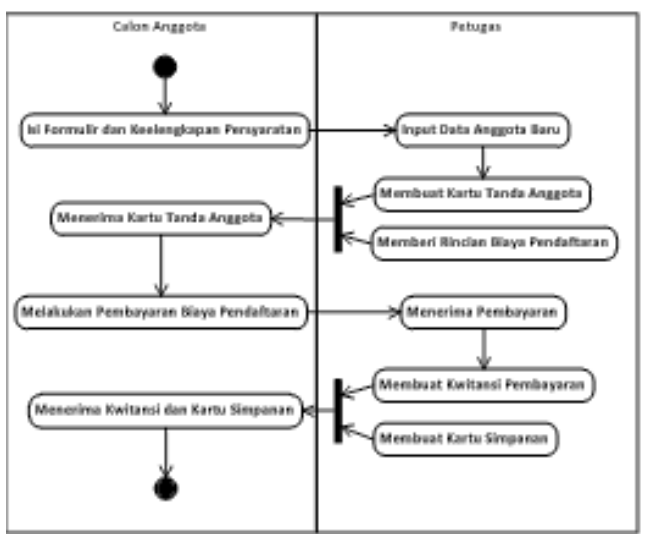

Gambar 2.

Activity Diagram Pendaftaran Anggota Sistem Berjalan

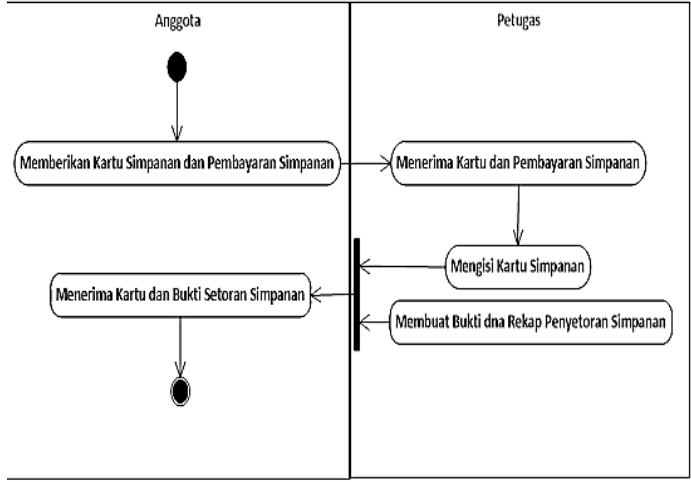

Gambar 3.

Activity Diagram Transaksi Simpanan Sistem Berjalan

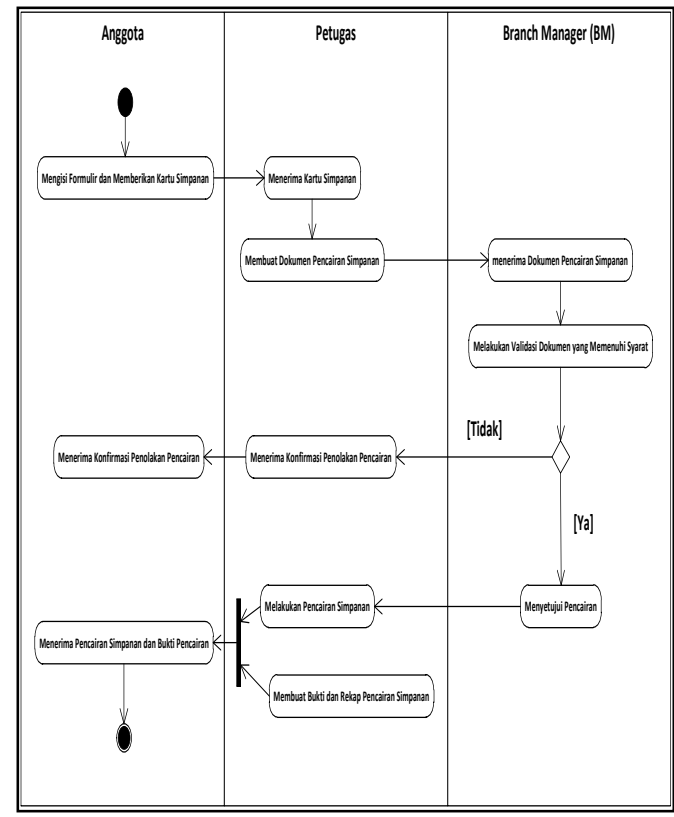

Gambar 4.

Activity Diagram Pengambilan Simpanan Sistem Berjalan

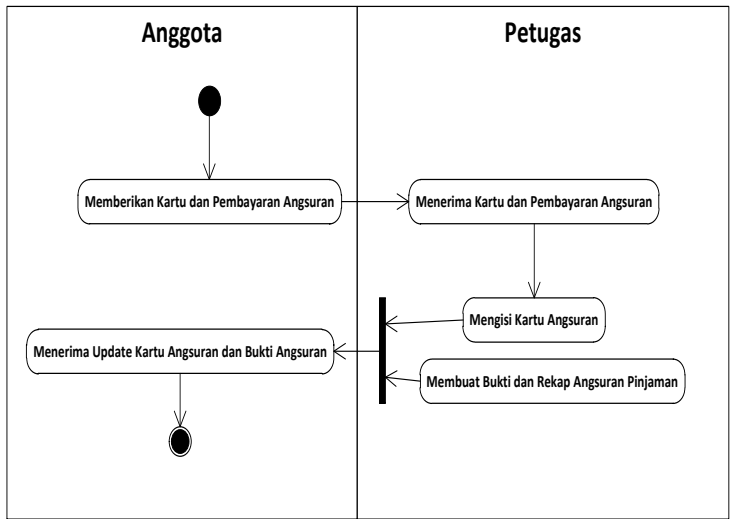

Gambar 5.

Activity Diagram pembayaran angsuran sistem berjalan. 


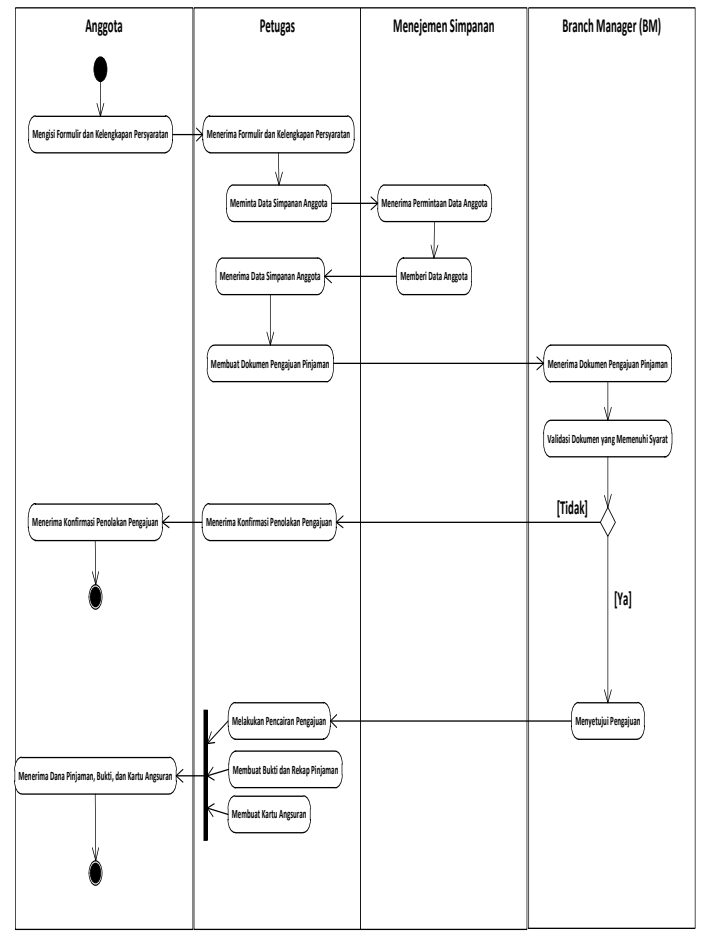

Gambar 6.

Activity Diagram Transaksi Pinjaman

Sistem Berjalan

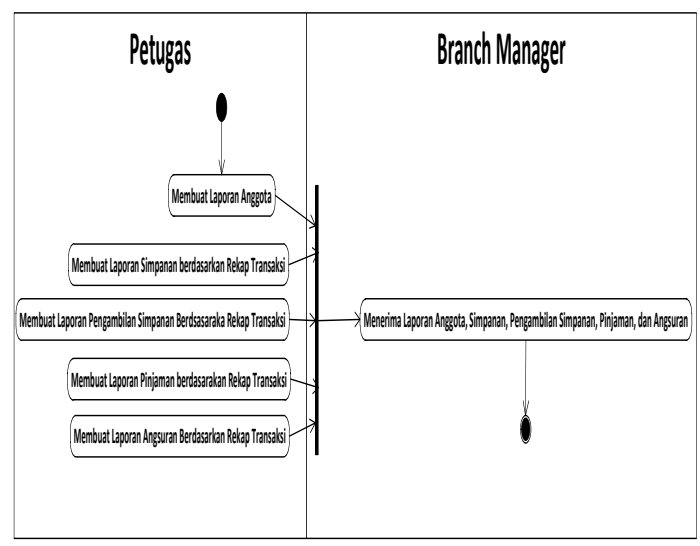

Gambar 7

Activity Diagram Pembuatan Laporan Sistem Berjalan

\section{Sistem Usulan}

Hasil dari penelitian ini berupa sebuah aplikasi sistem informasi simpan pinjam yang dibangun menggunakan perangkat lunak Microsoft Visual Basic 6.0 dan database Microsoft Office Access 2007, serta perangkat lunak yang digunakan untuk membuat output berupa laporan dari aplikasi ini adalah dengan menggunakan Crystal Report 8.5. Adapun kelas-kelas yang terbentuk dari basis data yang dibuat dijabarkan pada class diagram dan entity relationship diagram sebagai berikut:

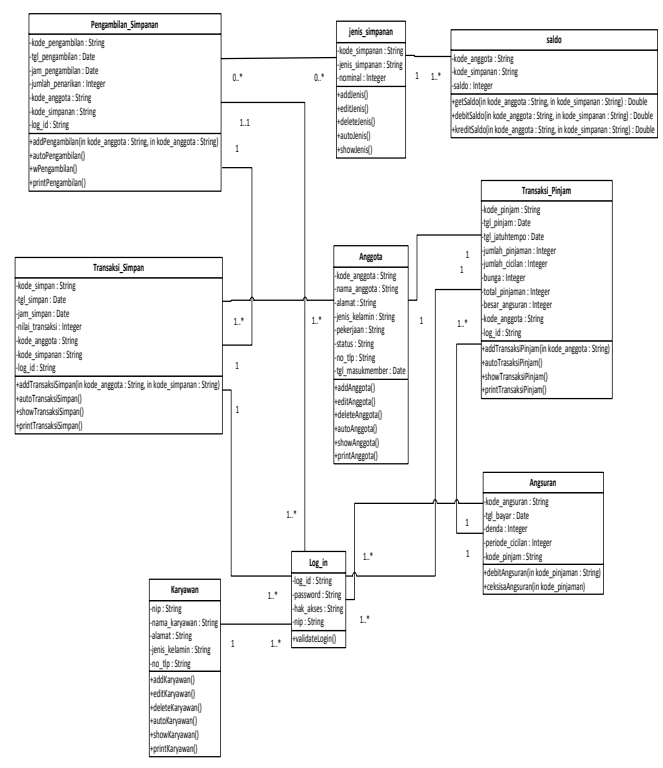

Gambar 8 .

Class Diagram Sistem Usulan

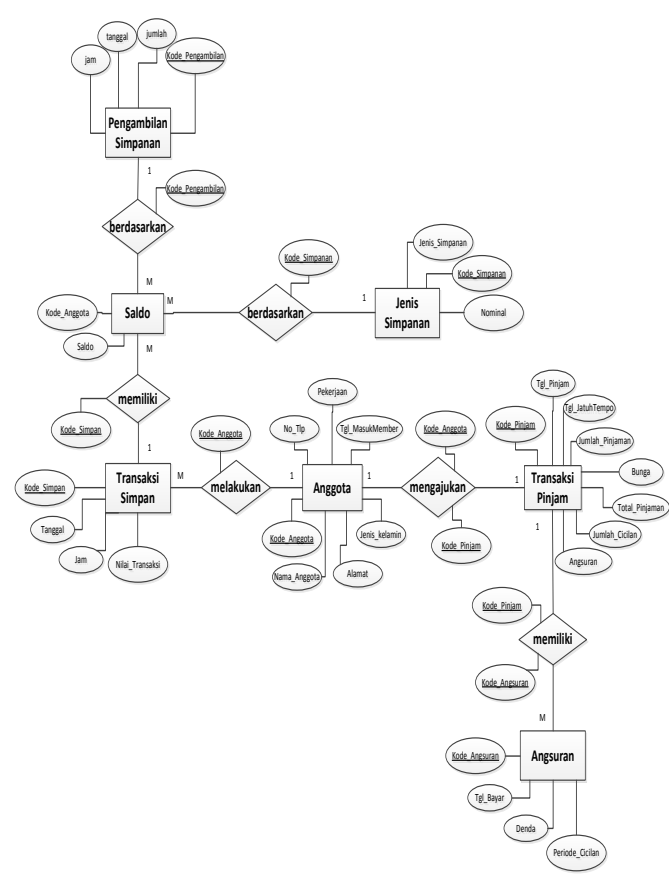

Gambar 9.

Entity Relationship Diagram Sistem Usulan

Dalam mengimplementasikan hasil program, digunakan user interface dengan hasil tampilannya dijabarkan sebagai berikut: 


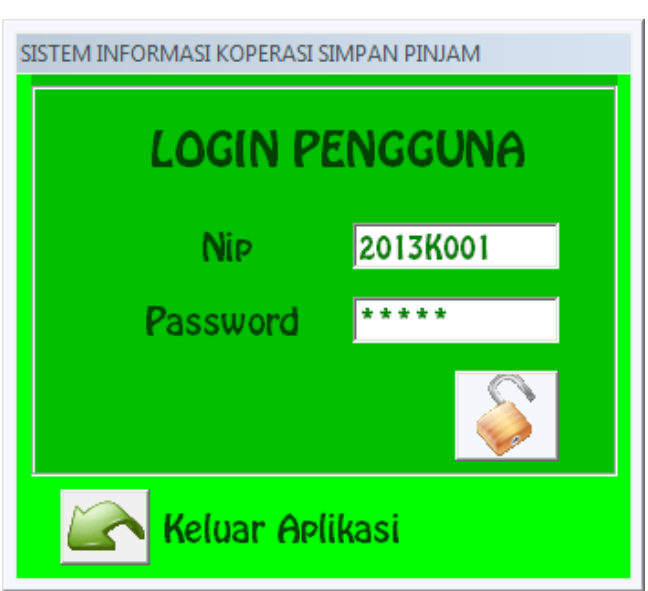

Gambar 10.

Antar Muka Form Login

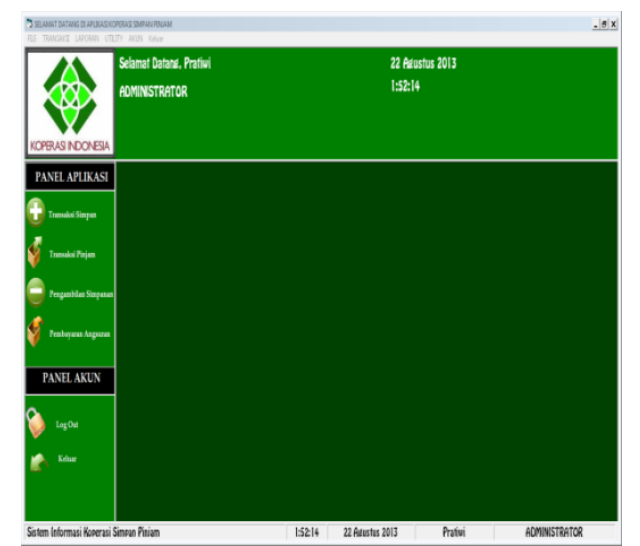

Gambar 11.

Antar Muka Form Menu Utama

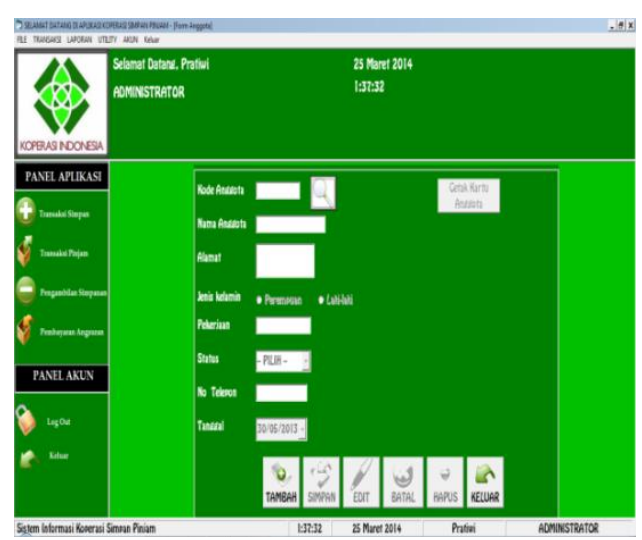

Gambar 12.

Antar Muka Form Anggota

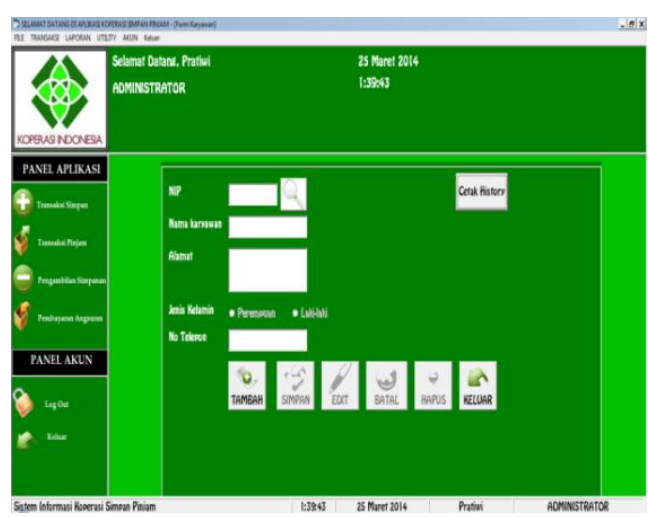

Gambar 13.

Antar Muka Form Karyawan

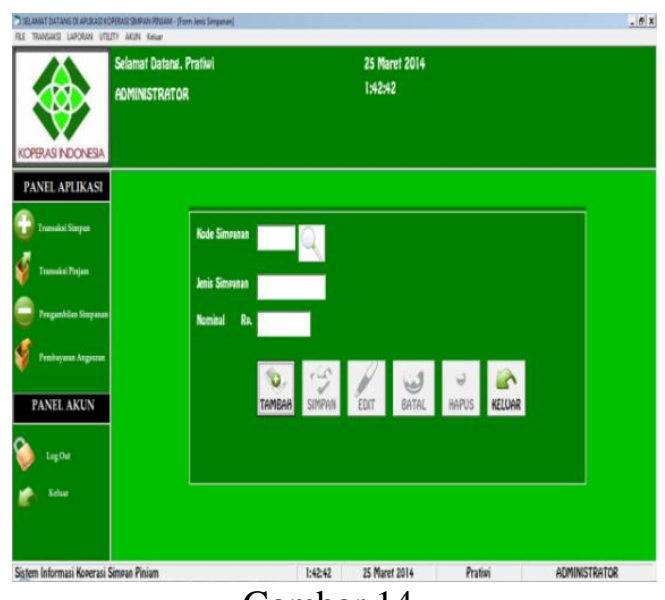

Gambar 14.

Antar Muka Form Jenis Simpanan

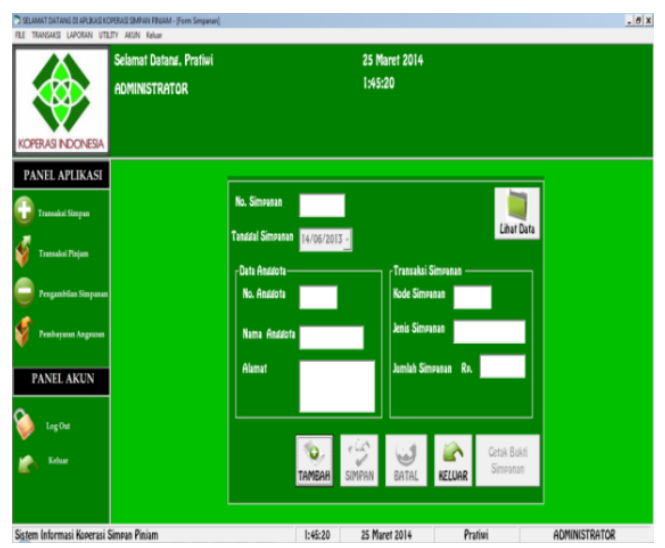

Gambar 15

Antar Muka Form Transaksi Simpan 


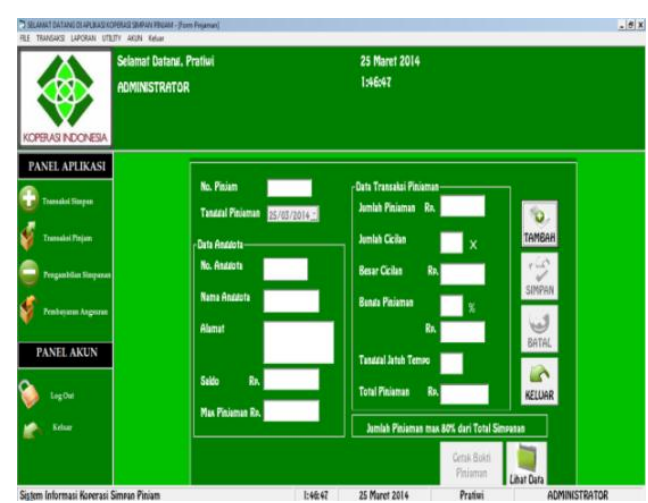

Gambar 16.

Antar Muka Form Transaksi Pinjam

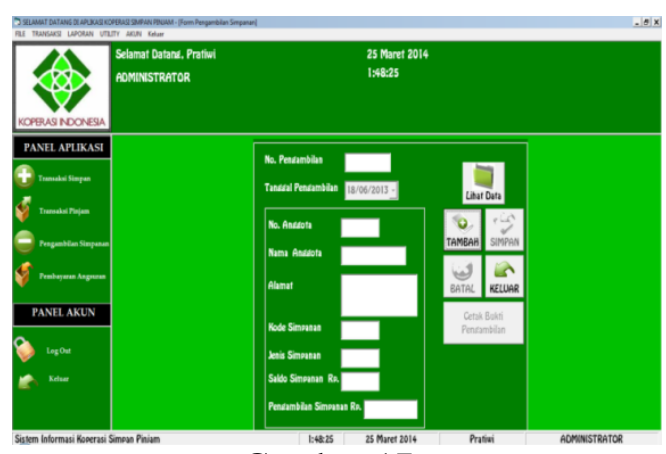

Gambar 17.

Antar Muka Form Pengembalian

Simpanan

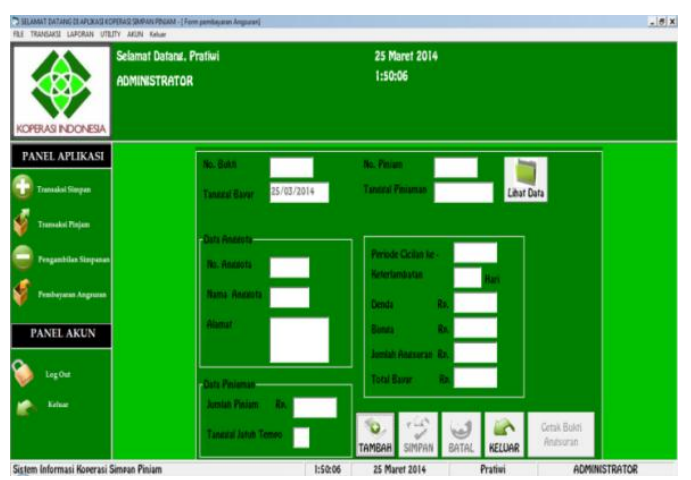

Gambar 18.

Antar Muka Form Pembayaran Angsuran

\section{PENUTUP}

Berdasarkan pada penelitian ini, secara garis besar dapat disimpulkan beberapa hal sebagai berikut :

1. Untuk membuat sebuah sistem informasi koperasi simpan pinjam ini, program yang digunakan adalah Micosoft Visual Basic 6.0 dengan menggunakan database Microsoft Office Access 2007 dan aplikasi pembuat laporan Crystal Report 8.5.
2. Secara garis besar langkah yang ditempuh untuk pembangunan sistem informasi ini dengan menggunakan metode waterfall dengan tahapan : mengumpulkan data, perancangan input dan output, perancangan program, dan implementasi program.

3. Sistem informasi memiliki kontrol yang dapat meminimalisir kesalahan kerja atau human error yang sering terjadi, sehingga kinerja suatu badan usaha bisa lebih meningkat karena setiap operasional berjalan lebih efektif dan efisien.

\section{REFERENSI}

1. Buku

[1] Jogiyanto, HM. Analisis dan Desain Sistem Informasi: Pendekatan Terstruktur Teori dan Praktek Aplikasi Bisnis, Andi, 2005, Yogyakarta.

[2] Jr, Lucas dkk. 1993. Desain dan implementasi Sistem Informasi. Jakarta: Erlangga.

[3] Kadir, Abdul., Konsep dan Tuntunan Praktis Basis Data, Andi, 1999, Yogyakarta.

[4] Kadir, Abdul., Pengenalan Sistem Informasi, Andi, 2003, Yogyakarta.

[5] Rusmawan, Uus. 20011. Visual Basic 6.0 Untuk Semua Tingkatan. Jakarta: PT.Elex Media Komputindo.

[6] Sutabri, Tata. 2004. Analisis \& Desain Sistem Informasi edisi ketiga. Yogyakarta: Andi

[7] Swastika, Windra. 2008. VB \& Mysql, Proyek Membuat general Ledger Seri 1. Jakarta: Dian Rakyat.

2. Artikel Jurnal

[8] Mawaddah, A., Hidayah, N. A., \& Zulfiandri. (2011). Rancang Bangun Sistem Informasi Simpan Pinjam Mudharabah pada 
Koperasi Baitul Maal Wat

Tamwil Ar-Rum. Jurnal Sistem

Informasi Vol.4 No.2, 2. 